Georgia State University

ScholarWorks @ Georgia State University

\title{
Transnational Activities of Immigrant-Owned Firms and Their Performances in the United States
}

\author{
Qingfang Wang \\ University of North Carolina Charlotte, qwang7@uncc.edu \\ Cathy Yang Liu \\ Georgia State University, cyliu@gsu.edu
}

Follow this and additional works at: https://scholarworks.gsu.edu/uwrg_workingpapers

\section{Recommended Citation}

Wang, Qingfang and Liu, Cathy Yang, "Transnational Activities of Immigrant-Owned Firms and Their Performances in the United States" (2015). UWRG Working Papers. 91.

https://scholarworks.gsu.edu/uwrg_workingpapers/91

This Article is brought to you for free and open access by the Usery Workplace Research Group at ScholarWorks @ Georgia State University. It has been accepted for inclusion in UWRG Working Papers by an authorized administrator of ScholarWorks @ Georgia State University. For more information, please contact scholarworks@gsu.edu. 


\section{W. J. Usery Workplace Research Group Paper Series}

Working Paper 2015-2-2

February 2015

\section{Transnational Activities of Immigrant- Owned Firms and Their Performances in the United States}

Qingfang Wang

University of North Carolina Charlotte

Cathy Yang Liu

Georgia State University

\section{ANDREW YOUNG SchOOL}




\title{
Transnational Activities of Immigrant-Owned Firms and \\ Their Performances in the United States
}

\author{
Qingfang Wang \\ University of North Carolina Charlotte \\ qwang7@uncc.edu \\ Cathy Yang Liu \\ Georgia State University \\ cyliu@gsu.edu \\ Published in Small Business Economics 2015
}

\begin{abstract}
Using microdata from the U.S. Survey of Business Owners (SBO) released in 2012, this study examines transnational activities of immigrant-owned businesses in three aspects: whether they export, outsource jobs, and have overseas establishments. Results show that immigrant-owned firms have significantly higher tendency to be involved in transnational economic activities when compared to non-immigrant owned firms. Immigrant firms without transnational activities have significantly smaller size of employees, annual total sales and total payrolls than non-immigrant firms. However, immigrant owned firms with transnational activities fare significantly better than non-immigrant owned firms without transnational activities. These findings speak directly to the long-debated issues concerning different motivations and performance outcomes of immigrant business ownership.
\end{abstract}

Keywords: immigrant entrepreneurship, transnational, internationalization, firm performance JEL: L26 


\section{Introduction}

With the continued influx of immigrants to the United States during the past several decades, the number of immigrant-owned businesses grew rapidly. Research indicates that entrepreneurship and business ownership provides an avenue of economic progress for immigrants (Appold and Kasarda 2004; Portes and Jensen 1989; Zhou and Cho 2010) as well as an important source of job creation, innovation, and economic growth. The most recent data show that immigrantowned firms generate over $\$ 775$ billion in revenue, $\$ 125$ billion in payroll, and $\$ 100$ billion in income, and employ one out of every ten workers. These firms include not only small businesses, but also $18 \%$ of all Fortune 500 companies (Kallick, 2012). It is not surprising that many governments have added programs to promote immigrant entrepreneurship for regional and local economic development (Ewing, 2012; Stafford, 2012). However, an "economic dead-end" perspective argues that many immigrants turned to self-employment mainly due to lack of human capital and blocked opportunities in the wage job market, and thus, immigrant business ownership provides no automatic social mobility and may even entrap ethnic minority labor force in the secondary labor market and "sweatshops" (Aldrich and Waldinger 1990; Barrett et al. 1996; Raijiman and Tienda 2000; Sanders and Nee 1987).

While such a debate is far from reaching a consensus (Nakhaie et al. 2009), most of these studies are based on immigrants' business activities in the low-skilled sectors (see Wang 2012 for a review). In recent years, a large and growing proportion of immigrants come with high levels of education and skill, and contribute disproportionately to the most dynamic part of the U.S. economy through creating new businesses and intellectual properties (Liu, Painter, \& Wang, 2014; Saxenian, 2006; Wadhwa et al., 2007). For instance, Hart et al. (2009) find that16 percent of high-impact, high-tech firms in the U.S. have at least one immigrant founder. In addition, 
immigrant owned firms have played an important role in promoting U.S. export. These new factors and forces call for a close examination of immigrant owned businesses under the current globalization context. In particular, how are immigrant owned businesses engaged in transnational economic activities? And how do such experiences speak to the aforementioned debates on the performance of immigrant owned businesses? In addressing these general inquires, this study investigates the characteristics of immigrant-owned businesses that have transnational economic activities, as well as how these activities are associated with their performances measured by employment, sales, and payroll.

Using microdata from the 2007 U.S. Survey of Business Owners (SBO), we define a firm as an immigrant owned firm if it has one or more foreign-born owners and its foreign-born owners have 51 percent or more of the stock or equity in the business. We measure transnational activities of immigrant-owned businesses in three aspects: whether they exports, outsource jobs, and have overseas establishments in comparison to non-immigrant owned firms. We find that immigrant owned firms have significantly higher tendency to be involved in transnational economic activities when compared to non-immigrant owned firms. Immigrant firms without transnational activities have significantly smaller size of employees, annual total sales and total payrolls than non-immigrant firms. However, when controlling for all other variables, immigrant owned firms with transnational activities have better performances than non-immigrant firms without transnational activities, if measured by employment, total sales, and total payrolls. Therefore, transnational economic activities are positively associated with improved economic prospects of immigrant owned firms. We also find that, if considering the size of employment, immigrant employer firms (i.e., those firms who have employees) have higher sales and lower payroll per employee, when compared to non-immigrant owned firms. While these results 
indicate that immigrant owned firms may operate more efficiently in terms of cost of labor, they may also imply an economic depreciation of employee skills in these firms as measured by wage or salary. However, immigrant firms with transnational activities have much higher sales and payroll per employee than firms without transnational activities.

While most existing international business literature is focused on mature multinational corporations, the transnational activities of small and medium sized enterprises have only recently started to attract broader interests (Miesenbock 1988; Ruzzier et al. 2006). Going beyond traditional studies of small immigrant businesses in low-skilled sectors, e.g., "enclave economies," the current study provides detailed account of the linkages between firm internationalization and performances, and, thus, bridging the two streams of literature, business internationalization and immigrant entrepreneurship together under the context of globalization. The current study indicates that immigrant businesses vary substantially in scale and performance. It is among the first attempts to provide a national profile of immigrant firms with transnational economic activities.

\section{Literature Review}

\section{Immigrant Ownership and Business Internationalization}

Recent years have witnessed expanded transnational activities among businesses (Coviello \& McAuley, 1999; Fischer \& Reuber, 2008; Reynolds, 1997). A wide range of factors are identified to be associated with internationalization of firms. For example, at the firm level, entrepreneur human capital (including international business skills, international orientation, environmental perception, and management know-how), social capital and social networking among firms, and firm characteristics (including number of employees and sales) are all relevant 
(Ruzzier et al. 2006). Etemad (2004) also finds that the entrepreneur's age, experience and international orientation plays a role in firm's decision to internationalize. At the macro environment level, the explosive growth of low-cost technology, dismantling of trade barriers and financial deregulation, the widespread economic restructuring and liberalization, as well as the geographical expansion of markets in Asia and the BRIC region, have all facilitated the transnational activities of firms (Acs et al., 2001; Gjellerup, 2000).

From a network perspective, Johanson and Vahlne (1990, p. 20) define internationalization as the "process of developing networks of business relationships in other countries through extension, penetration, and integration." They directly conceptualize the connections between different countries as a key element for the formation of economic activities cross the country borders. In immigrant entrepreneurship literature, a large number of studies have documented the role of social networks based on ethnicity and nationality in explaining immigrants' entrepreneurial entry dynamics, motivations and forms of their transnational activities. For example, ethnic affinity and cultural distinctiveness form the basis of labor recruitment for immigrant and ethnic members and allow them privileged access to niche labor markets (Wilson and Portes 1980; Portes and Jensen 1989; Zhou 1992). For immigrant and ethnic business owners, belonging to a particular ethnic group and using its associated network could act as an informal business incubator and provide varying physical and intellectual ethnic resources, such as labor, capital, supplier, and markets (Alder and Kwon 2002; Portes 1998). In addition, internationalization entrepreneurship literature (Lehtinen and Penttinen, 1999; Reid 1981) has argued that international orientation (i.e., a firm's general attitude towards internationalization) and international commitment are key factors to make firms' international activities happen and sustain. Consistently, some studies on immigrant entrepreneurship have 
focused on cultural practices and heritages as explanations to why immigrants often are more prepared than non-immigrants to start their own businesses (Light and Rosenstein 1995). For example, researchers have argued that Koreans are culturally predisposed toward entrepreneurship, a trait they bring with them from their country of origin (Fawcett and Gardner 1994). Indeed, Portes et al.(2002) found that transnationals represent a significant portion of all immigrant entrepreneurs; and that transnational activities were not a function of years in the U.S. or economic status, but of the historical context of migration.

Therefore, as immigrants rely on their home-country connections as well as co-ethnic networks and clientele, they might have a natural propensity to internationalize in their business practices. At the same time, it is possible that it is more likely for immigrants who have transnational ties to identify differences between foreign markets and the home market space along economic, cultural, political, and market-strategic dimensions. Given these discussions, it is our first hypothesis to test whether immigrants are more likely to internationalize their businesses and what are the individual and business characteristics associated with such internationalization.

\section{Hypothesis 1: Immigrant owned firms are more likely to have transnational activities}

\section{than non-immigrant owned firms.}

\section{Transnational activities and Immigrant Firm Performance}

From a social capital and social network perspective, researchers argue that immigrant entrepreneurs and businesses may rely on invaluable information on market opportunities, a ready source of ethnic labor, credit, knowledge of consumer preferences, critical consumer markets for businesses that cater to specialized ethnic tastes. All these open up possibilities to serve underserved or deserted markets and penetrate markets with low economies of scale, and 
establish foreign branches in their home countries (Miera, 2008; Portes and Jensen 1987; Zhou 1992; Waldinger et al. 1990; Wilson and Portes 1980). .

Despite immigrant entrepreneurs' stronger transnational ties, immigrant business sectors are often portrayed as low-skilled, low pay, unstable, with poor working conditions, and "sweatshops" for co-ethnic immigrant labor force (Doeringer \& Piore, 1971; Hudson, 2007; Sanders \& Nee, 1987). Researchers argue that entrepreneurial entry provides an alternative route of economic advancement for immigrant workers when they face "blocked opportunities" in the formal labor market as a result of limited English language skill, depreciation of their home country-acquired human capital, and discrimination from employers. An "economic dead-end" perspective further argues that minority business ownership provides no social mobility but simply entails "a horizontal shift in which disadvantage is perpetually in another guise" (Barrett, Jones, \& McEvoy, 1996, p. 787). Consistently, ethnically or immigrant bounded social networking could exist as an ethnic, spatial and sectoral enclosure that traps entrepreneurs in acutely constrained market (Bates \& Robb, 2008; Deakins, Smallbone, Ishaq, Whittam, \& Wyper, 2009; Kaplan \& House-Soremekun, 2009; Kitching, Smallbone, \& Athayde, 2009). While most existing studies on ethnic businesses are focused on low-skilled and small businesses, their experiences do not speak directly to immigrant business with transnational activities. More recently, immigrant entrepreneurs start to play an increasingly important role in the high-technology industry with $25.3 \%$ of the engineering and technology companies established between 1995 and 2005 had at least one immigrant key founder (Wadhwa et al 2007; Liu et al. 2014). The transnational entrepreneurs travel abroad frequently for their work and their success depend on business activities with foreign countries, including their own country of origin (Drori, Honig, \& Wright, 2009; Portes, 2003; Portes, Guarnizo, \& Haller, 2002). For 
instance, in Silicon Valley, the transnational flow of ideas, human capital and financial capital between immigrant entrepreneurs and their home countries in the Asia Pacific expanded their business opportunities and fueled the fast growth of the regional economy (Saxenian et al 2002).

Thus, these new global-oriented immigrant entrepreneurs would distinguish substantially from their traditional enclave-bounded predecessors in terms of their business scale, scope, and performance. A study of Polish entrepreneurs to Germany observed that these business owners took advantage of differences in purchasing power and personal mobility for trade between home and host country; recruited Polish workers; marketed to the local co-ethnic market; and opened locations in their home country (Miera, 2008). Kariv et al. (2009) studied the role of transnational networks on the success of ethnic entrepreneurs and found that ethnicity shaped the types of networking (formal vs. informal), and thus the success rates by various metrics, especially sales and survival. Based on firm-level analyses in Canada, Neville et al. (2014) find that young immigrant-owned exporter firms outperformed young domestically-founded firms in general; however, immigrant-owned young enterprises that did not export underperformed other young firms. It suggests that export played a positive role in young immigrant firms' performance.

In sum, these perspectives on the motivation of immigrants' entrepreneurial entry and their business types yield different predictions on their business performance. On the one hand, the survivalist perspective argue that transnational activities of immigrant owned businesses are mainly a "natural" and cultural extension through their social networking which may not necessarily bring economic benefits; on the other hand, accounts of new opportunities under the globalization context would expect that transnational linkages can significantly enhance their business success. In light of these debates, this study will test a set of hypotheses related to firm 
performances of immigrant-owned firms with transnational linkages in terms of employment size, total sales/receipts, and sales/receipts per employee.

- Hypothesis 2a: Compared to firms without transnational activities, immigrant firms with transnational activities are more likely to be employer firm (firms that have employees), or have larger employment size for employer firms;

- Hypothesis 2b: Compared to firms without transnational activities, immigrant firms with transnational activities have higher annual sales and annual payroll.

\section{Data and Methodology:}

\section{Data}

The U.S. Survey of Business Owners (SBO) provides a comprehensive, regularly collected dataset on the economic characteristics of businesses and selected demographic characteristics of business owners including gender, ethnicity, race, and foreign-born status. Data have been collected every 5 years since 1972 and most recently available data, 2007 SBO, is used for this study. Its sample includes all nonfarm businesses filing Internal Revenue Service tax forms with receipts of $\$ 1,000$ or more that existed in year 2007. We use the Survey of Business Owners (SBO) Public Use Microdata Sample (PUMS) which was released in August 2012.

\section{Definitions and Measurements}

Immigrant ownership. Following the definition by the U.S. Census bureau, we define a firm as an immigrant owned firm if it has one or more foreign-born owners and these foreignborn owners have 51 percent or more of the stock or equity in the business ${ }^{1}$. If the firm's US-

\footnotetext{
${ }^{1}$ We understand that the owner's function in a firm has multiple dimensions in addition to financial control. For example, the style and strategies of daily management significantly affect business operation and performance. Labor force recruitment, market information analyses, forefront interaction with customers, which are especially important when dealing with transnational transactions may not be executed by the owners who have the financial
} 
born owners have 51 percent or more of the stock or equity in the business, we define it as a USborn owned firm. For simplicity, we interchangeably use the term of "immigrant owned firms" with "immigrant firm" and "US-born owned firms" with "native firm."

Transnational economic activities. The criteria for measuring the degree of transnational activity of a firm have been a subject of debate in international business literature (Cavusgil, 1984; Fischer \& Reuber, 2008; Sullivan, 1994). This study adopts the idea from the "The Uppsala model (U-model)" which was developed by Johanson \& Wiedersheim-Paul (1975). In this model, four steps are indentified by Uppsala school as key components in the sequential process of firm internationalization: (1) Irregular export activities; (2) Export through independent agents; (3) Establishment of an overseas sales subsidiary; and (4) Overseas production or manufacturing units. We define "transnational" as having any or all of the three types of activities including export, having overseas establishment, and outsource jobs. The U.S. SBO asks three questions related to transnational linkages. First, "what percent of this business' total goods and/or services consisted of exports outside of the Unites States?" Second, "Did this business establish operations outside the United States?" Third, "Did this business outsource or transfer any business function and/or service to a company outside the United States?” By using this survey data, if a business answers "yes" to any of these three questions, we define them as a “transnational" firm. We also present results on treating these three dimensions separately. While not providing any structural attributes of the businesses, these indicators indeed capture a wide range of economic activities (such as market, supply, labor force, and branch) through

control but by the owners who manage day-to-day operations, who directly provide services or produce goods, or who perform other functions. Therefore, we test our results by defining a firm as an immigrant-owned firm once there is one foreign-born owner. Results from regression do not significantly differ from our current observation qualitatively. 
transnational connection. In particular, overseas establishment and outsourcing are seldom examined in existing studies.

Firm Performance. Following the literature and given SBO data availability, business performance in this study is measured by employment size, sales revenue (by receipt value), and payrolls. Employment size is measured by (1) being an employer firm (i.e., firms have employees) or a non-employer firm (i.e., firms without employees, such as self-employment); and (2) the number of employees for employer firms. Employer and non-employer firms are very different in nature in terms of financial sources, business types, and management strategies. Generally speaking, employer firms tend to have larger volumes of sales and payrolls than nonemployer firms. Therefore, employer firms and non-employer firms are examined separately in this study. In consideration of the firm size, we not only look at total sales and payroll of every firm, but also examine sales per employee and payroll per employee for employer firms. To a certain extent, these per capita performance measures could reflect level of operational efficiency or different strategies of human capital cost reduction.

\section{Empirical Models}

To test the first research hypothesis on immigrant ownership and transnational linkages, a logistic regression is employed to evaluate the association between immigrant ownership and the probability of being engaged in transactional activities (export, overseas operation, and/or outsource). A logit regression is conducted which is given by:

$$
\mathrm{Y}=\beta \mathrm{X}+\varepsilon, \mathrm{Y}_{\mathrm{i}} \in\{0,1\}, \varepsilon \sim \mathrm{N}\left(0, \sigma^{2}\right)
$$

where the dependent variable $\mathrm{Y}$ is the (log) odds of having transnational economic activities. $\mathrm{X}$ is the matrix of independent variables representing firm and the primary owner's characteristics. We control for a series of characteristics at both business owner and firm level to test the 
hypotheses. Based on existing studies on internationalization and immigrant entrepreneurship as discussed in earlier literature review (e.g., Etemad, 2004; Ruzzier et al. 2006; Neville et al. 2014), these variables include: age, gender, and level of education of the primary owner, whether he or she has prior self-employment experience, when the business was established, whether the business is home-based, whether the business has individuals or businesses as customers, whether it has e-commerce, and whether it is family-owned (the complete list is provided by Table 4).

For the second set of research hypotheses, the dependent variable is firm performance along three dimensions: employment size, total sales and payrolls, and sales and payroll per employee.

Employment size. To gauge the relationship between employment and transnational economic activities, a logistic regression in a similar form as formula (1) is used for all firms. The dependent variable is the (log) odds of being an employer firm versus non-employer firm, $\mathrm{X}$ is the matrix of independent variables representing firm and the primary owner's characteristics. We are particularly interested in the relationship between immigrant ownership and transnational economic activities. Therefore, interaction terms between immigrant-ownership and transnational activities are included in the model. The results will indicate to what extent transnational activities are associated with being an employer firm; and in particular, how the association is contingent on immigrant ownership. In addition, a linear regression is conducted with the sample of employer firms to examine the characteristics associated with the number of employees.

Sales and Payroll. In order to examine the relationship between sales and transnational activities, a linear regression model is used. To control for the influence of the firm size, we 
conduct the analysis separately for non-employer firms and employer firms. For non-employer firms, the dependent variable is the annual sales (in natural logarithm form). For employer firms, both the total annual sales and total annual payroll are examined. The independent variables are the same as those in the employment models, with the interaction terms between immigrant ownership and transnational economic activities as variables of concern. In order to take out possible bias caused by size on total sales and total payroll, we also examine sales per employee and payroll per employee for employer firms as additional tests.

\section{Results and Discussion}

\section{Overview}

Of all the firms in the sample, about 12.6 percent of them are immigrant owned firms and about $15.5 \%$ of total firms have at least one foreign-born owner. As shown in Table 1, 5.7 percent of all firms have some transnational activities while the rate is 5.5 percent for the native-born and 9.0 percent for immigrant firms. Their participation in the three different types of transnational activates vary, with the highest share in exporting, followed by outsourcing and then having overseas establishments for both native and immigrant firms. The data provide the racial and ethnic identity of business owners, but not the country of origin for the foreign-born business owners. Of all the native owned firms, 5.6 percent of non-Hispanic white owned firms have transnational activities, and the figures are 3.1 percent for non-Hispanic blacks, 5.3 percent for Hispanics, and 7.3 percent for Asians. Among the immigrant firms, the percentage of firms with transnational activities for whites, blacks, Hispanics, and Asians is 9.8, 6.6, 7.6 and 9.3, respectively. Overall, immigrant-owned firms have much higher propensity for participating in transnational activities, regardless of racial/ethnic identity.

<Table 1 about here> 
Table 2 shows performance as measured by employment size, sales, and payroll (total and per employee), separately by employer and non-employer firm, for both native and immigrant firms. Immigrant-owned firms have a higher share of employer firms than nativeowned firms. Among the employer firms, immigrant firms have lower performance on all the indicators than their native counterparts. However, when transnational activities are considered, transnational immigrant firms outperform other firms without transnational activities. Native owned firms with transnational activities have the best business performance measured by these indicators. For non-employer firms, immigrant firms have higher average annual sales than native firms and thus immigrant firms with transnational activities outperform all other groups. Native firm without transnational activities rank the lowest. Such patterns suggest that immigrant firms are very diverse and it is necessary to examine employer and non-employer firms separately. It is also interesting to note that immigrant employer firms have much higher average sales per employee and much lower average payroll per employee than non-immigrant firms, regardless of transnational activities.

$<$ Table 2 about here>

Table 3 presents the mean statistics of three sets of independent variables: owner characteristic, firm level characteristics, and industry characteristics for immigrant- and nativeowned firms with and without transnational activities. Generally speaking, regardless of immigrant status, the primary business owners of transnational firms tend to be male, older, have higher level of education, and are more likely to have former experiences of self-employment. While non-Hispanic whites dominate the native-born firms, the immigration-owned firms are much more ethnically diverse. At the firm level, transnational firms tend to be more established, more likely to have businesses as customers, have e-commerce, be family owned, less likely to 
be home-based, and less likely to have individuals or households as customers as compared to other firms across the board.

In terms of business sectors, all the firms regardless of immigrant ownership status, have a higher presence in the sector of "Professional, Scientific, and Technical Services". In addition to this sector, transnational firms in general have larger shares in wholesale and retail trade. Meanwhile, native firms with transnational activities have a larger share in manufacturing. Firms without transnational activities have relatively larger shares in the sectors of construction, Finance, Real Estate and Rental and Leasing (FIRE), and all service sectors.

$<$ Table 3 about here>

\section{H1: Immigrant ownership and firms' transnational activities}

Table 4 presents the relationship between immigrant ownership and the probability of having transnational activities, while controlling for owner and firm characteristics. As defined earlier, transnational activities refer to any activity of export, having overseas establishments, or outsourcing jobs (Model 1). At the same time, Table 4 also displays the results from each of the three types of activities in Model 2 (export), Model 3 (overseas establishment), and Model 4 (outsource jobs). It is consistent with our hypothesis that immigrant owned firms are more likely than non-immigrant owned firms to have transnational economic activities in all measurements. Specifically, when controlling for other characteristics, the odds of having transnational activities will increase by 92 percent $(=1-\exp (0.657))$ for an immigrant firm when compared with nonimmigrant owned firms (Model 1). Likewise, compared to non-immigrant-owned firms, the likelihood of having overseas establishments will increase by 1.6 times (Model 3), and the likelihood of job outsourcing will increase by 1.2 times for immigrant owned firms (Model 4), if holding other conditions the same. 
Based on earlier discussion of existing literature, it is possible that immigrant business owners' natural linkages with their home countries could work as a bridge leading their businesses to the transnational markets. Furthermore, at the business owner level, the cultural heritage and experiences of business ownership in their home country could play a role. For instance, compared to firms owned by non-Hispanic whites, Hispanic owned firms or firms with mixed-racial ownership are more likely to have transnational economic activities. Although Asian firms do not show significant difference from white firms for the entire national data sample, among all native owned firms (results are not shown here), US-born Asian owned firms, along with firms with Hispanic and mix-racial ownership, are more likely to have transnational activities than US-born white owned firms.

In addition, we find that family owned firms are more likely to have transnational linkages than non-family owned firms, if other conditions are the same. The interaction term between immigrant ownership and family ownership is also positive. It suggests that family owned immigrant firms have better opportunities to access international network. Such a pattern reinforces the idea that social network by nationality/ethnicity, kinship, and family ties possibly endows unique resources for immigrant entrepreneurs to capitalize on.

$<$ Table 4 about here>

Not all firms can take the opportunity to be involved with transnational activities. According to the results, firms with the prime owners who are male, have a college degree, and have prior self-employment experiences are more likely to have transnational economic activities than firms without such business owner(s). At the firm level, firms with a longer tenure, have businesses as customers, and have ecommerce are more likely to have transnational activities. These patterns suggest a higher level of human capital endowment is associated with firm 
internationalization. Among all the industrial sectors, manufacturing firms are the most likely to have transnational economic activities, regardless of immigration status. This is consistent with the earlier descriptive statistics we have observed.

Overall, our findings suggest that immigrant entrepreneurs are more likely to engage in transnational activities given their human capital and social capital that are more conducive for navigating through the international context, as well as the possibility to develop routines and decision-making mechanisms based on their historical home country environments (Kiesler and Sproull 1982; Neville et al., 2014).

\section{H2a: Transnational activities and employment size}

Table 5 presents how transnational activities or linkages are associated with size of employees. Model 1 is a logit regression for all firms, with the dependent variable as "being an employer firm or not." Model 2 is linear regression for employer firms only, with the number of employees as the dependent variable. In order to examine the relationship between immigrant ownership and transnational economic activities in their association with firm performance, we include an interaction term between these two variables for each model.

After controlling for all other variables in the model, immigrant firms are less likely to be an employer firms than non-immigrant firms (Model 1). However, transnational firms are more likely to be an employer firm than non-transnational firms. Specifically, compared to firms without transnational economic activities, transnational firms are 27 percent $(1-\exp (0.241))$ more likely to be an employer firm. The interaction term between immigrant-ownership and transnational activities is not significant. However, if an immigrant firm has transnational activities, its probability of being an employer firms will still significantly increase. Likewise, 
among employer firms (model 2), immigrant owned firms are smaller than non-immigrant owned employer firms. But, having transnational activities is significantly associated with a larger size of employees. Overall, we find that transnational activities have significantly changed the employment profile for immigrant firms when compared to firms without transnational activities. This indicates that transnational activities and internationalization could provide immigrant firms greater potential to grow. It also suggests that immigrant firms without transnational linkages are the most disadvantaged for long-term development.

$<$ Table 5 about here>

Firms with a primary business owner who is male, has a college degree, and has prior experiences of self-employment are more likely to be an employer firm and tend to have a larger employment size. Non-Hispanic white owned firms are the most likely to have a firm with employees and have a larger size of employment among employer firms. Compared to firms in manufacturing, firms in construction, wholesale, utility, transportation, and professional sectors are more likely to have employees. But employer firms in these sectors tend to be smaller when compared to manufacturing employer firms.

\section{H2b: Transnational activities and total annual sales and payroll}

As shown in Table 6, immigrant owned employer firms have lower total sales and payrolls than non-immigrant owned employer firms, holding all other conditions the same (the Employer Model) while this is not true for non-employer firms (the Non-Employer Model). Consistent with our hypothesis, having transnational activities is positively associated with higher annual sales (for both employer and non-employer firms) and annual payroll (employer firms only). Specifically, if controlling for all other variables, total sales for transnational firms are about 4550 percent higher than non-transnational firms, for both employer and non-employer firms. A 
similar pattern holds true for total payrolls for employer firms. The interaction term between immigrant ownership and transnational activities is not significant for either employer or nonemployer models. Nonetheless, the overall effect of transnational activities is still positive for immigrant firms. Similar to the employment model, transnational immigrant firms outperformed the non-transnational firms, regardless immigrant owned or not, if measured by total sales and payroll.

\section{$<$ Table 6 about here>}

To control for the scale effect, we also examined sales per employee (left panel of Table 7) and payroll per employee (right panel of Table 7) for employer firms. All else the same, immigrant firms have higher sales per employee than comparable non-immigrant firms regardless of transnational linkages, and transnational firms have significantly higher sales per employee. The interaction term between transnational linkage and immigrant status is also significantly positive. These results are different from total employment, total annual sales and payroll models presented earlier where non-immigrant owned firms with transnational activities perform better than all other three groups (i.e., immigrant transnational firms, non-immigrant non-transnational firms, and immigrant non-transnational firms).

\section{$<$ Table 7 about here>}

For the payroll model, immigrant firms have lower payrolls per employee than nonimmigrant firms if controlling for other conditions. This supports earlier finding that immigrant firms not only have smaller size (from the total employment and total payrolls model) but also possibly pay a lower wage. On the one hand, immigrant owned firms may operate more efficiently for several reasons. Established networks, better knowledge of culture, operation, market opportunities, and lower cost of labor could all have contributed to such an advantage of 
immigrant owned firms. On the other hand, such a pattern may imply an economic depreciation of employee skills in immigrant owned firms as measured by wage or salary. For example, family labor and ethnicity or nationality based linkages could have provided resources in recruiting low-cost labor (e.g., lower pay and/or long working hours). Although this data sample does not provide direct evidence on this issue, some existing studies, e.g., those linking sweatshop and co-ethnic exploitation in immigrant and ethnic businesses (Green, 1996; Hum, 2003; Waldinger \& Lapp, 1993), suggest the need for further research in this area.

Transactional activities are positively associated with higher payroll per employee. Immigrant firms with transnational activities have much higher payroll per employee than both immigrant and non-immigrant firms without transnational activities. Furthermore, the interaction term between immigrant ownership and transnational activities is positive as well. It suggests that immigrant firms with transnational activities pay significantly higher wages, than both immigrant and non-immigrant firms without transnational activities.

Consistent with many studies in the field of international business and entrepreneurship that posits a positive association between firm internationalization and firm performance (e.g., Lu and Beamish, 2001; Shrader and Siegel, 2007). Neville et al. (2012, p7) argue that exportoriented immigrant-owned enterprises are able to "acquire, manage, and lever important knowledge-creating resources (e.g. social capital, information, and knowledge)," which in turn lead to enhanced performance. Although our data do not allow examination of causality and specific mechanisms between transitional activities and firm performance, our findings generally support the hypothesis that immigrant entrepreneurs' ability to lever international linkages and experience is likely to generate stronger performance through internationalization process. In addition, employees at transnational immigrant firms seem to receive higher wages than those in 
domestically-oriented immigrant firms Compared to the dominant literature on exploitation and sweatshop in immigrant businesses, this unexplored area deserves much future research.

\section{Conclusion}

Using the first publicly available firm-level data from the U.S. Survey of Business Owners, this study examines businesses' transnational activities defined in three dimensions: export, having overseas establishment, and outsourcing jobs, with an explicit comparison between immigrant owned and non-immigrant owned firms. Existing literature has provided different, in some cases even contrasting, perspectives on motivation and performance of immigrant businesses. At the same time, although transnational activities become increasingly important under the current global economy, studies on transnational activities of immigrant owned firms are rare.

Addressing the debates and gaps of knowledge, the current study finds some interesting patterns to highlight.

First, immigrant owned firms have significantly higher tendency to be involved in transnational economic activities when compared to non-immigrant owned firms, even after considering many firm-level and business owner-level characteristics. While it is possible that limited opportunities in wage labor market may have pushed immigrants to turn to selfemployment, we believe cultural factors, especially established linkages with home country could play a significant role in promoting transnational economic activities for immigrant owned firms. Referring back to the debate on immigrant entrepreneurship, these immigrants are more likely to establish businesses out of perceived opportunity than necessity.

Immigrant firms have a higher proportion of employer firms than non-immigrant firms. However, after controlling for other characteristics, immigrant firms are less likely to employ workers. Further, among employer firms, immigrant firms have significantly smaller size of 
employment. Among non-employer firms, immigrant firms tend to have higher total sales than non-immigrant firms after controlling for other characteristics. At the same time, for both employer and non-employer firms, transnational activities are significantly associated with higher annual sales. This indicates that immigrant owned firms are running in a "low-cost" way featured by a smaller size of employees and higher sales. The same pattern seems stronger if we consider the size of employment. For employer firms, immigrant owned firms have higher sales per employee and lower payroll per employee when compared with non-immigrant owned firms. The advantage becomes more significant if firms have transnational economic activities.

These results directly speak to the existing debates about rationales and performances for immigrant owned firms. First of all, transnational firms are alike in their characteristics and business types, regardless of owner's immigrant status. At the same time, immigrant businesses vary in scale and performance. It may be true that immigrants have resources such as access to international networks that provide them competitive advantage over non-immigrant owners who aspire to set up transnational linkages. However, not all immigrant business owners are able to lever such advantages. In fact, transnational firms are only a small proportion of all firms.

While calling for more studies on transnational economic activities of immigrant enterprises, these results also suggest policy implications in tapping into existing transnational linkages between US firms and overseas markets. Existing studies have documented the positive impacts of immigrant owned businesses. For instance, transnational entrepreneurial activities between Silicon Valley and Asian pacific countries have benefited businesses and entrepreneurship infrastructure building on both sides (Price \& Chacko, 2009; Saxenian, 2007; Zhou \& Hsu, 2011). In non-high tech industry, Chin et al. (1996) shows a strong vertical integration developed between Korean wig manufacturers in South Korea and Korean importers, 
wholesalers, and retails in the U. S. which has provided Korean immigrants with initial business opportunities in the U.S. Eckstein and Nguyen (2011) also shows formal and informal ethnic network has helped the Vietnamese establishment, transformation, and transnationalization of an urban employment niche in the beauty industry. While more and more immigrant sending countries are capitalizing their diaspora networks through explicit public policy initiatives (Faist, 2008; Kuznetsov, 2006; Singer \& Senor, 2011), the policies to cope with and capitalize into these programs on the immigrant-receiving side should be further explored.

\section{References}

Acs, Z.J., Morck, R.K., \& Yeung, B. (2001). Entrepreneurship, globalisation, and public policy. Journal of International Management, 7: 235-51.

Adler, Paul S, \& Kwon, Seok-Woo. (2002). Social capital: prospects for a new concept. Academy of management review, 27(1), 17-40. doi: 10.5465/AMR.2002.5922314

Aldrich, Howard E, \& Waldinger, Roger. (1990). Ethnicity and entrepreneurship. Annual Review of Sociology, 111-135. DOI: 10.1146/annurev.so.16.080190.000551

Antoncic, Bostjan, \& Hisrich, Robert D. (2001). An Integrative Conceptual Model. Journal of Euromarketing, 9(2), 17-35. doi: 10.1300/J037v09n02_02

Appold, S. J. \& Kasard, J.D. (2004). Building community through entrepreneurship: Lessons from Vietnam and the United States. In Butler, J and Kozmetsky, G., editors, Immigrant and minority entrepreneurship: Building American communities, Westport, CT: Greenwood Press, 61-84.

Barrett, Giles A., Jones, Trevor P., \& McEvoy, David. (1996). Ethnic Minority Business: Theoretical Discourse in Britain and North America. Urban Studies, 33(4/5), 783-809. doi: 10.1080/00420989650011825

Bates, Timothy, \& Robb, Alicia. (2008). Analysis of young neighborhood firms serving urban minority clients. Journal of Economics and Business, 60(1), 139-148. doi: http://dx.doi.org/10.1016/j.jeconbus.2007.09.004

Cavusgil, S. Tamer. (1984). Differences among exporting firms based on their degree of internationalization. Journal of Business Research, 12(2), 195-208. doi: 10.1016/01482963(84)90006-7

Chetty, Sylvie, \& Agndal, Henrik. (2007). Social Capital and Its Influence on Changes in Internationalization Mode Among Small and Medium-Sized Enterprises. Journal of International Marketing, 15(1), 1-29. doi: 10.1509/jimk.15.1.001

Chin, Ku-Sup, Yoon, In-Jin, \& Smith, David. (1996). Immigrant small business and international economic linkage: A case of the Korean wig business in Los Angeles, 1968-1977. International Migration Review, 485-510. DOI: 10.2307/2547391 
Chrysostome, Elie, \& Xiaohua, Lin. (2010). Immigrant entrepreneurship: Scrutinizing a promising type of business venture. Thunderbird International Business Review, 52(2), 77-82. doi: 10.1002/tie.20315

Contractor, Farok J., Kundu, Sumit K., \& Hsu, Chin-Chun. (2003). A Three-Stage Theory of International Expansion: The Link between Multinationality and Performance in the Service Sector. Journal of International Business Studies, 34(1), 5-18. doi: $10.2307 / 3557136$

Coviello, Nicole E., \& McAuley, Andrew. (1999). Internationalisation and the smaller firm: a review of contemporary empirical research. Management International Review (MIR), 39(3), 223-256.

Dalziel, Margaret. (2008). Immigrants as Extraordinarily Successful Entrepreneurs: A Pilot Study of the Canadian Experience. Journal of Small Business and Entrepreneurship, 21(1), 23-36. DOI: 10.1080/08276331.2008.10593411

Deakins, David, Smallbone, David, Ishaq, Mohammed, Whittam, Geoffrey, \& Wyper, Janette. (2009). Minority ethnic enterprise in Scotland. Journal of ethnic and migration studies, 35(2), 309-330. DOI:10.1080/13691830802586468

Doeringer, Peter B, \& Piore, Michael J. (1971). Internal labor markets and manpower analysis: ME Sharpe Inc.

Drori, Israel, Honig, Benson, \& Wright, Mike. (2009). Transnational Entrepreneurship: An Emergent Field of Study. Entrepreneurship Theory and Practice, 33(5), 1001-1022. doi: 10.1111/j.1540-6520.2009.00332.x

Eckstein, Susan, \& Nguyen, Thanh - Nghi. (2011). The Making and Transnationalization of an Ethnic Niche: Vietnamese Manicurists. International Migration Review, 45(3), 639-674. DOI: 10.1111/j.1747-7379.2011.00861.x

Ensign, Prescott C., \& Robinson, Nicholas P. (2011). Entrepreneurs because they are Immigrants or Immigrants because they are Entrepreneurs? Journal of Entrepreneurship, 20(1), 3353. doi: 10.1177/097135571002000102

Etemad, Hamid. (2004). Internationalization of Small and Medium-sized Enterprises: A Grounded Theoretical Framework and an Overview. Canadian Journal of Administrative Sciences / Revue Canadienne des Sciences de l'Administration, 21(1), 1-21. doi: 10.1111/j.1936-4490.2004.tb00319.x

Ewing, Walter. (2012, November 30). Immigrants May Hold the Key to Urban Renewal in Baltimore. Retrieved from http://immigrationimpact.com/2012/11/30/immigrants-mayhold-the-key-to-urban-renewal-in-baltimore/

Fairlie, Robert W. (2012). Open for Business: How Immigrants Are Driving Small Business Creation in the United States (pp. 40): Partnership for a New American Economy.

Faist, Thomas. (2008). Migrants as transnational development agents: an inquiry into the newest round of the migration-development nexus. Population, space and place, 14(1), 21-42. DOI: $10.1002 / p s p .471$

Fan, Terence, \& Phan, Phillip. (2007). International New Ventures: Revisiting the Influences behind the 'Born-Global' Firm. Journal of International Business Studies, 38(7), 1113 1131. doi: $10.2307 / 4540481$

Fawcett, James T, \& Gardner, Robert W. (1994). Asian immigrant entrepreneurs and nonentrepreneurs: A comparative study of recent Korean and Filipino immigrants. Population \& Environment, 15(3), 211-238. DOI: 10.1007/BF02208201 
Fischer, Eileen, \& Reuber, Becky. (2008). Survival of the fittest: Which SMEs internationalize most extensively and effectively? (pp. 31): The Conference Board of Canada.

Gjellerup, P. (2000). SME support services in the face of globalisation. Concerted action seminar, Opening address, Conference Proceedings, Danish Agency for Trade and Industry, Copenhagen, 16-28.

Green, Nancy L. (1996). Women and Immigrants in the Sweatshop: Categories of Labor Segmentation Revisited. Comparative Studies in Society and History, 38(03), 411-433.

Haltiwanger, John and Jarmin, Ron S. (2007) Integrated Longitudinal Business Database: Data Overview. Available at SSRN: http://ssrn.com/abstract=1022119

Hart, David M. (2010). What Do Foreign-Born Founders Bring to Entrepreneurial Teams? An Exploration in the U.S. High-Tech Sector. GMU School of Public Policy Research Paper No. 2011-06.

Hiebert, Daniel. (2002). Economic associations of immigrant self-employment in Canada. International Journal of Entrepreneurial Behaviour \& Research, 8(1/2), 93-112. DOI: http://dx.doi.org/10.1108/13552550210423741

Hudson, Kenneth. (2007). The new labor market segmentation: Labor market dualism in the new economy. Social Science Research, 36(1), 286-312. doi: http://dx.doi.org/10.1016/j.ssresearch.2005.11.005

Hum, Tarry. (2003). Mapping Global Production in New York City's Garment Industry: The Role of Sunset Park, Brooklyn's Immigrant Economy. Economic Development Quarterly, 17(3), 294-309. doi: 10.1177/0891242403255088

Johanson, J. \& Vahlne, J.E. (1990). The mechanism of internationalization. International Marketing Review, 7(4),11-24.

Johanson, J. \& Wiedersheim-Paul, F. (1975). The internationalization of the firm - four Swedish cases. Journal of Management Studies, 2(3), 305-322.

Kallick, David Dyssegaard. (2012). Immigrant Small Business Owners: A Significant and Growing Part of the Economy Immigration Research Initiative. New York: Fiscal Policy Institute.

Kaplan, David H, \& House-Soremekun, Bessie. (2009). Entrepreneurship and neighbourhood among African Americans in Cleveland, Ohio. International Journal of Business and Globalisation, 3(3), 256-270. DOI: 10.1504/IJBG.2009.023498

Kariv, Dafna, Menzies, Teresa V., Brenner, Gabrielle A., \& Filion, Louis Jacques. (2009). Transnational networking and business performance: Ethnic entrepreneurs in Canada. Entrepreneurship \& Regional Development, 21(3), 239-264. doi: 10.1080/08985620802261641

Kitching, Dr John, Smallbone, David, \& Athayde, Rosemary. (2009). Ethnic diasporas and business competitiveness: Minority-owned enterprises in London. Journal of ethnic and migration studies, 35(4), 689-705. DOI: 10.1080/13691830902765368

Kuznetsov, Yevgeny N. (2006). Diaspora networks and the international migration of skills: how countries can draw on their talent abroad: World Bank Publications.

Lehtinen, U. \& Penttinen, H. (1999). "Definition of the internationalization of the firm", in Lehtinen, U. and Seristoe, H. (Eds), Perspectives on Internationalization, Helsinki School of Economics and Business Administration, Helsinki, pp.3-19.

Li, Peter S. (1994). Self-employment and its economic return for visible minorities in Canada. New Approaches to Employee Management, 2, 181-199. 
Li, Peter S. (1997). Self-employment among visible minority immigrants, white immigrants, and native-born persons in secondary and tertiary industries of Canada. Canadian Journal of Regional Science, 20(1), 103-118.

Li, Peter S. (2000). Economic returns of immigrants' self-employment. Canadian Journal of Sociology/Cahiers canadiens de sociologie, 1-34.

Light, Ivan Hubert. (1972). Ethnic enterprise in America: Business and welfare among Chinese, Japanese, and Blacks: Univ of California Press.

Light, Ivan Hubert. (2007). Women's economic niches and earnings inferiority: The view from the ethnic economy. Journal of ethnic and migration studies, 33(4), 541-557. DOI: 10.1080/13691830701265412

Light, I. \& Rosenstein, C. (1995). Race, ethnicity, and entrepreneurship in urban America. New York: Aldine De Gruyter.

Liu, C.Y., Painter, G. and Wang, Q. (2014). Lessions for Metro AreasCharacteristics and Clustering of High-Tech Immigrant Entrepreneurs. Ewing Marion Kauffman Foundation White Paper.

Lu, J.W. \& Beamish, P.W. (2001). The internationalization and performance of SMEs. Strategic Management Journal, 22 (6-7), 565-586.

McDougall, Patricia Phillips, \& Oviatt, Benjamin M. (2000). International Entrepreneurship: The Intersection of Two Research Paths. The Academy of Management Journal, 43(5), 902906. doi: $10.2307 / 1556418$

Miera, Frauke. (2008). Transnational Strategies of Polish Migrant Entrepreneurs in Trade and Small Business in Berlin. Journal of ethnic and migration studies, 34(5), 753-770. doi: 10.1080/13691830802106010

Miesenbock, K.J. (1988). Small business and exporting: a literature review. International Small Business Journal, 6(2), 42-61.

Mustafa, Michael, \& Chen, Stephen. (2010). The strength of family networks in transnational immigrant entrepreneurship. Thunderbird International Business Review, 52(2), 97-106. doi: $10.1002 /$ tie. 20317

Nakhaie, Reza, Lin, Xiaohua, \& Guan, Jian. (2009). Social capital and the myth of minority selfemployment: evidence from Canada. Journal of ethnic and migration studies, 35(4), 625644. DOI: 10.1080/13691830902765244

Neville, F., Orser, B., Riding, A., \& Jung, O. (2014). Do young firms owned by recent immigrants outperform other young firms? Journal of Business Venturing, 29(1), 55-71.

Portes, A. (1998). Social capital: Its origins and application in modern sociology. Annual Review of Sociology, 24(1), 1-24.

Portes, Alejandro. (2003). Conclusion: Theoretical Convergencies and Empirical Evidence in the Study of Immigrant Transnationalism. International Migration Review, 37(3), 874-892. doi: 10.1111/j.1747-7379.2003.tb00161.x

Portes, Alejandro, Guarnizo, Luis Eduardo, \& Haller, William J. (2002). Transnational Entrepreneurs: An Alternative Form of Immigrant Economic Adaptation. American Sociological Review, 67(2), 278-298. doi: 10.2307/3088896

Portes, A., and Jensen, L. (1989). The enclave and the entrants: Patterns of ethnic enterprise in Miami before and after Mariel. American Sociological Review, 54(6): 929-49.

Price, Marie, \& Chacko, Elizabeth. (2009). The Mixed Embeddedness of Ethnic Entrepreneurs in a New Immigrant Gateway. Journal of Immigrant \& Refugee Studies, 7(3), 328-346. doi: $10.1080 / 15562940903150105$ 
Raijman, Rebeca, \& Tienda, Marta. (2000). Immigrants' pathways to business ownership: A comparative ethnic perspective. International Migration Review, 682-706. DOI: $10.2307 / 2675942$

Ramaswamy, Kannan, Kroeck, K. Galen, \& Renforth, William. (1996). Measuring the Degree of Internationalization of a Firm: A Comment. Journal of International Business Studies, 27(1), 167-177. doi: 10.2307/155377

Reid, S.D. (1981). The decision-maker and export entry and expansion. Journal of International Business Studies, 12(2), 101-12.

Reynolds, P.D. (1997). New and small firms in expanding markets. Small Business Economics, 9(1), 79-84. doi: 10.1023/A:1007916217140

Ruzzier, Mitja, Hisrich, Robert D., \& Antoncic, Bostjan. (2006). SME internationalization research: past, present, and future. Journal of Small Business and Enterprise Development, 13(4), 476-497. doi: http://dx.doi.org/10.1108/14626000610705705

Shrader, R. \& Siegel, D.S. (2007). Assessing the relationship between human capital and firm performance: evidence from technology-based new ventures. Entrepreneurship Theory and Practice, 31 (6), 893-908

Sanders, Jimy M, \& Nee, Victor. (1987). Limits of ethnic solidarity in the enclave economy. American Sociological Review, 745-773.

Saxenian, AnnaLee. (2007). The New Argonauts: Regional Advantage in a Global Economy. Cambridge, MA: Harvard University Press.

Singer, Saul, \& Senor, Dan. (2011). Start-up nation: The story of Israel's economic miracle: McClelland \& Stewart.

Stafford, Bill. (2012). Seattle's Korean community: How immigration makes us all stronger. Crosscut.com. http://crosscut.com/2012/11/21/culture-ethnicity/111416/bill-stafford-koreancommunity-business/

Sullivan, Daniel G. (1994). Measuring the Degree of Internationalization of a Firm. Journal of International Business Studies, 25(2), 325-342. doi: 10.2307/155392

U.S. Small Business Administration (USSBA). (2011). Developments in Women-owned Business, 1997-2007.

Waldinger, R., Aldrich, H.,\& Ward, R. (1990). Ethnic entrepreneurs: immigrant business in industrial societies. Newbury Park, CA: Sage Publications.

Waldinger, Roger, \& Lapp, Michael. (1993). Back to the Sweatshop or Ahead to the Informal Sector?*. International Journal of Urban and Regional Research, 17(1), 6-29. doi: 10.1111/j.1468-2427.1993.tb00209.x

Wang, Q. (2012). Ethnic Entrepreneurship Studies in Geography: A Review. Geography Compass, 6(4), 227-240.

Wilson, Kenneth L., \& Portes, Alejandro. (1980). Immigrant Enclaves: An Analysis of the Labor Market Experiences of Cubans in Miami. The American Journal of Sociology, 86(2), 295-319.

Zhou, M. (1992). Chinatown: The socioeconomic potential of an urban enclave. Philadelphia: Temple University Press.

Zhou, M. and Cho, M. (2010). Noneconomic effects of ethnic entrepreneurship: Evidence from Chinatown and Koreatown in Los Angeles, USA. Thunderbird International Business Review 52 (2). 
Zhou, Yu, \& Hsu, Jinn-Yuh. (2011). Divergent engagements: roles and strategies of Taiwanese and mainland Chinese returnee entrepreneurs in the IT industry. Global Networks, 11(3), 398-419. doi: 10.1111/j.1471-0374.2010.00302.x

Table1. Percentage of Firms with Transnational Activities by Immigrant Ownership

\begin{tabular}{|c|c|c|c|}
\hline & All & Native & Immigrant \\
\hline Have exports & 5.1 & 5.1 & 7.9 \\
\hline Have overseas establishments & 0.7 & 0.5 & 1.6 \\
\hline Have outsourcing & 0.7 & 0.6 & 1.8 \\
\hline Any Transnational & 5.7 & 5.5 & 9.0 \\
\hline
\end{tabular}

Note: "Any Transnational" means having any of the above three.

Source: Authors' calculation of Survey of Business Owners 2007 data.

Table 2. Performances by Immigrant Ownership and Transnational Activities

\begin{tabular}{|c|c|c|c|c|c|c|c|}
\hline & \multicolumn{3}{|c|}{ Native-owned } & \multicolumn{3}{|c|}{ Immigrant-owned } \\
\hline & & All & $\begin{array}{l}\text { Trans- } \\
\text { national }\end{array}$ & $\begin{array}{l}\text { Nontrans } \\
\text {-national }\end{array}$ & All & $\begin{array}{l}\text { Trans- } \\
\text { national }\end{array}$ & $\begin{array}{l}\text { Nontrans- } \\
\text { national }\end{array}$ \\
\hline \multicolumn{2}{|c|}{$\begin{array}{l}\text { Share of employer } \\
\text { firms (\%) }\end{array}$} & 30.90 & 46.10 & 30.00 & 33.20 & 44.90 & 32.00 \\
\hline \multirow{5}{*}{$\begin{array}{l}\text { Employer } \\
\text { firm }\end{array}$} & $\begin{array}{l}\text { Size in } \\
1,000\end{array}$ & $\begin{array}{l}12.54 \\
(87.82)\end{array}$ & $\begin{array}{l}23.54 \\
(110.11)\end{array}$ & $\begin{array}{l}11.54 \\
(85.17)\end{array}$ & $\begin{array}{l}8.55 \\
(45.29)\end{array}$ & $\begin{array}{l}12.29 \\
(58.39)\end{array}$ & $\begin{array}{l}8.04 \\
(43.24)\end{array}$ \\
\hline & $\begin{array}{l}\text { Payroll in } \\
1,000\end{array}$ & $\begin{array}{l}435.16 \\
(3299.62)\end{array}$ & $\begin{array}{l}1039.85 \\
(5530.58)\end{array}$ & $\begin{array}{l}380.50 \\
(3004.92)\end{array}$ & $\begin{array}{l}260.99 \\
2422.35)\end{array}$ & $\begin{array}{l}557.37 \\
(5728.4)\end{array}$ & $\begin{array}{l}220.11 \\
(1459.9)\end{array}$ \\
\hline & $\begin{array}{l}\text { Sales in } \\
1,000\end{array}$ & $\begin{array}{l}2020.89 \\
(21803.09)\end{array}$ & $\begin{array}{l}6318.90 \\
(42671.3)\end{array}$ & $\begin{array}{l}1829.09 \\
(18702.1)\end{array}$ & $\begin{array}{l}1461.84 \\
(18269.22)\end{array}$ & $\begin{array}{l}4195.59 \\
(44253.39)\end{array}$ & $\begin{array}{l}1083.75 \\
(10402.26)\end{array}$ \\
\hline & $\begin{array}{l}\text { sales per } \\
\text { employee } \\
\text { in } 1,000\end{array}$ & $\begin{array}{l}189.49 \\
(608.9) \\
\end{array}$ & $\begin{array}{l}319.32 \\
(1236.54)\end{array}$ & $\begin{array}{l}177.20 \\
(601.66) \\
\end{array}$ & $\begin{array}{l}207.04 \\
(657.22)\end{array}$ & $\begin{array}{l}414.38 \\
(1317.06)\end{array}$ & $\begin{array}{l}177.46 \\
(490.58)\end{array}$ \\
\hline & $\begin{array}{l}\text { payroll per } \\
\text { employee } \\
\text { in } 1,000\end{array}$ & $\begin{array}{l}35.29 \\
(74.72)\end{array}$ & $\begin{array}{l}43.75 \\
(86.68)\end{array}$ & $\begin{array}{l}34.49 \\
(73.49)\end{array}$ & $\begin{array}{l}30.22 \\
(44.37)\end{array}$ & $\begin{array}{l}40.73 \\
(50.13)\end{array}$ & $\begin{array}{l}28.75 \\
43.36)\end{array}$ \\
\hline $\begin{array}{l}\text { Non- } \\
\text { Employer }\end{array}$ & $\begin{array}{l}\text { Sale in } \\
1,000\end{array}$ & $\begin{array}{l}58.37 \\
(183.36)\end{array}$ & $\begin{array}{l}84.44 \\
(229.01)\end{array}$ & $\begin{array}{l}57.24 \\
(181.14)\end{array}$ & $\begin{array}{l}64.25 \\
(195.79)\end{array}$ & $\begin{array}{l}105.14 \\
(265.88)\end{array}$ & $\begin{array}{l}61.02 \\
(189.11)\end{array}$ \\
\hline
\end{tabular}

Note: numbers in parentheses are standard deviation from the mean.

Source: Authors' calculation of Survey of Business Owners 2007 data. 
Table 3. Descriptions of primary business owners and firms

\begin{tabular}{|c|c|c|c|c|}
\hline & \multicolumn{2}{|c|}{ Native-Owned } & \multicolumn{2}{|c|}{ Immigrant-Owned } \\
\hline & $\begin{array}{l}\text { Trans- } \\
\text { national }\end{array}$ & $\begin{array}{l}\text { Nontrans- } \\
\text { national }\end{array}$ & \begin{tabular}{|l|} 
Trans- \\
national \\
\end{tabular} & $\begin{array}{l}\text { Nontrans- } \\
\text { national }\end{array}$ \\
\hline \multicolumn{5}{|l|}{ Primary Owner Characteristics } \\
\hline female & 18.96 & 23.54 & 19.63 & 25.99 \\
\hline male & 59.96 & 54.24 & 63.76 & 58.75 \\
\hline Gender-equal & 21.09 & 22.22 & 16.61 & 15.26 \\
\hline$<35$ years old & 3.91 & 6.85 & 7.15 & 9.88 \\
\hline $35-54$ years old & 40.60 & 47.34 & 52.97 & 58.01 \\
\hline$>55$ years old & 55.49 & 45.80 & 39.88 & 32.12 \\
\hline Bachelor degree & 60.56 & 52.64 & 63.50 & 47.48 \\
\hline Self-employment Experience & 48.72 & 44.10 & 50.88 & 42.76 \\
\hline Non-Hispanic white & 92.53 & 92.34 & 39.75 & 36.93 \\
\hline Non-Hispanic black & 1.45 & 2.45 & 3.07 & 3.88 \\
\hline Hispanic & 2.39 & 2.26 & 18.58 & 22.58 \\
\hline Non-Hispanic Asian & 0.96 & 0.66 & 35.04 & 33.53 \\
\hline Mixed-Racial & 2.67 & 2.28 & 3.56 & 3.08 \\
\hline \multicolumn{5}{|l|}{ Firm Characteristics } \\
\hline Established before 80 & 17.17 & 12.88 & 6.27 & 5.95 \\
\hline Established 80-90 & 17.44 & 15.72 & 10.92 & 10.05 \\
\hline Established 90-99 & 25.79 & 25.54 & 27.70 & 23.36 \\
\hline Established 2000-07 & 39.60 & 45.86 & 55.10 & 60.63 \\
\hline Home based & 46.65 & 53.63 & 44.68 & 40.86 \\
\hline Business as customer & 59.04 & 36.65 & 61.97 & 28.63 \\
\hline Individual as customer & 58.26 & 74.53 & 51.06 & 77.99 \\
\hline Have e-Commerce & 40.67 & 6.48 & 24.50 & 4.17 \\
\hline Family owned & 36.81 & 32.68 & 31.93 & 25.62 \\
\hline \multicolumn{5}{|l|}{ Industrial distribution } \\
\hline Agriculture and mining & 1.2 & 1.6 & 0.3 & 0.4 \\
\hline Construction & 3.6 & 12.5 & 2.4 & 9.4 \\
\hline Manufacturing & 12.5 & 2.4 & 6.1 & 2.0 \\
\hline Wholesale & 12.8 & 2.6 & 19.7 & 2.7 \\
\hline Retail & 20.1 & 9.6 & 15.8 & 10.7 \\
\hline Utility/transportation/Warehouse & 3.5 & 3.0 & 4.8 & 6.2 \\
\hline Information\& Communication & 3.8 & 1.3 & 3.1 & 1.0 \\
\hline FIRE & 4.7 & 16.1 & 4.8 & 11.4 \\
\hline $\begin{array}{l}\text { Professional\& } \\
\text { management }\end{array}$ & 21.3 & 23.9 & 26.3 & 20.5 \\
\hline Social services & 10.0 & 14.5 & 8.2 & 15.2 \\
\hline Personal services & 6.6 & 12.5 & 8.4 & 20.5 \\
\hline $\mathrm{N}$ & 356690 & 5449088 & 87535 & 739630 \\
\hline
\end{tabular}


Note: They are all percentages since all the variables are in categorical format.

Source: Authors' calculation of Survey of Business Owners 2007 data

Table 4. Logit Regression Results on Transnational Activities

\begin{tabular}{|c|c|c|c|c|c|c|c|c|}
\hline Variables & All trans & Std. Err. & export & Std. Err. & overseas & Std. Err. & outsource & Std. Err. \\
\hline immigrant owned & 0.644 & 0.01 & 0.621 & 0.02 & 0.940 & 0.03 & 0.739 & 0.03 \\
\hline Immig*Family own & 0.042 & 0.02 & 0.017 & 0.02 & 0.064 & 0.05 & 0.211 & 0.04 \\
\hline \multicolumn{9}{|l|}{ Control Variable } \\
\hline Non-Hispanic black & -0.374 & 0.03 & -0.451 & 0.03 & 0.183 & 0.06 & -0.297 & 0.07 \\
\hline Hispanic & 0.076 & 0.02 & 0.061 & 0.02 & 0.339 & 0.04 & 0.234 & 0.04 \\
\hline Non-Hispanic Asian & 0.006 & 0.02 & -0.123 & 0.02 & 0.150 & 0.04 & 0.550 & 0.03 \\
\hline Mixed-Racial & 0.184 & 0.02 & 0.138 & 0.02 & 0.544 & 0.05 & 0.379 & 0.04 \\
\hline family owned & 0.117 & 0.01 & 0.130 & 0.01 & 0.070 & 0.02 & 0.014 & 0.02 \\
\hline female & -0.226 & 0.01 & -0.211 & 0.01 & -0.432 & 0.03 & -0.298 & 0.02 \\
\hline Gender-equal & -0.228 & 0.01 & -0.218 & 0.01 & -0.421 & 0.03 & -0.287 & 0.03 \\
\hline age35-54 & -0.056 & 0.02 & 0.022 & 0.02 & -0.222 & 0.04 & -0.356 & 0.03 \\
\hline$>$ age55 & -0.054 & 0.02 & 0.040 & 0.02 & -0.195 & 0.04 & -0.549 & 0.04 \\
\hline Bachelor degree & 0.414 & 0.01 & 0.380 & 0.01 & 0.608 & 0.02 & 0.596 & 0.02 \\
\hline Self-employment & 0.123 & 0.01 & 0.105 & 0.01 & 0.197 & 0.02 & 0.293 & 0.02 \\
\hline Est80-90 & -0.155 & 0.01 & -0.148 & 0.01 & -0.135 & 0.03 & -0.069 & 0.03 \\
\hline Est90-99 & -0.253 & 0.01 & -0.277 & 0.01 & -0.177 & 0.03 & -0.010 & 0.03 \\
\hline Est2000-07 & -0.439 & 0.01 & -0.490 & 0.01 & -0.257 & 0.03 & -0.003 & 0.03 \\
\hline Homebased & -0.250 & 0.01 & -0.251 & 0.01 & -0.166 & 0.02 & -0.296 & 0.02 \\
\hline Bus. as customer & 0.565 & 0.01 & 0.586 & 0.01 & 0.239 & 0.03 & 0.766 & 0.03 \\
\hline Ind. as customer & -0.572 & 0.01 & -0.562 & 0.01 & -0.761 & 0.03 & -0.515 & 0.02 \\
\hline e-Commerce & 1.630 & 0.01 & 1.672 & 0.01 & 1.103 & 0.02 & 1.173 & 0.02 \\
\hline Agriculture & -1.637 & 0.04 & -1.684 & 0.04 & -0.258 & 0.09 & -1.417 & 0.12 \\
\hline Construction & -2.454 & 0.02 & -2.581 & 0.02 & -1.179 & 0.06 & -1.801 & 0.06 \\
\hline Wholesale & -0.165 & 0.01 & -0.166 & 0.01 & 0.143 & 0.04 & -0.305 & 0.03 \\
\hline Retail & -0.755 & 0.01 & -0.761 & 0.01 & -0.231 & 0.04 & -0.775 & 0.04 \\
\hline Utility\&transport & -0.999 & 0.02 & -1.019 & 0.02 & 0.024 & 0.05 & -0.345 & 0.04 \\
\hline Infor\&Communi & -0.767 & 0.02 & -0.915 & 0.02 & 0.078 & 0.05 & 0.226 & 0.04 \\
\hline FIRE & -2.293 & 0.02 & -2.537 & 0.02 & -0.729 & 0.05 & -1.129 & 0.04 \\
\hline Professional & -1.339 & 0.01 & -1.521 & 0.01 & -0.099 & 0.03 & -0.254 & 0.03 \\
\hline Social services & -1.711 & 0.02 & -1.830 & 0.02 & -0.396 & 0.05 & -1.007 & 0.05 \\
\hline Personal services & -1.751 & 0.02 & -1.794 & 0.02 & -0.898 & 0.06 & -1.465 & 0.06 \\
\hline Inercept & -1.274 & 0.02 & -1.357 & 0.03 & -4.347 & 0.06 & -4.234 & 0.05 \\
\hline LR chi2 & 165362 & & 163971 & & 12950 & & 21164 & \\
\hline Prob > chi2 & 0.000 & & 0.000 & & 0.000 & & 0.000 & \\
\hline Pseudo R2 & 0.231 & & 0.247 & & 0.101 & & 0.136 & \\
\hline $\mathrm{N}$ & 1024898 & & 1000636 & & 1023663 & & 1023420 & \\
\hline
\end{tabular}


Table 5. Model Results on Employer Firm Status and Size of Employment for Employer Firms

\begin{tabular}{|l|l|l|l|l|}
\hline & \multicolumn{2}{|l|}{ Model 1- All Firms } & \multicolumn{2}{l|}{ Model 2- Employer Firms } \\
\hline & Employer or not & Std. Err. & Size & Std. Err. \\
\hline Transnational & 0.2409 & 0.01 & 0.1450 & 0.01 \\
\hline Immigrant owned & -0.1243 & 0.01 & -0.1810 & 0.01 \\
\hline Transnational * immigrant & 0.0012 & 0.02 & 0.0045 & 0.01 \\
\hline Intercept & 1.5098 & 0.02 & 2.6751 & 0.01 \\
\hline LR chi2 & 329842 & & & \\
\hline Prob > chi2 & 0.0000 & & & \\
\hline Pseudo R2 & 0.25 & & & \\
\hline Adjusted R-Squire & & & 0.25 & \\
\hline $\mathrm{N}$ & 1024898 & & 588424 & \\
\hline
\end{tabular}

Note: Model 1 is conducted for all firms from a logit regression with "having employee(s) or not" as the dependent variable; Model 2 is conducted for employer firms only from a linear regression with the size of employees as the dependent variable. The control variables (not shown) are the same as those in Table 4.

Table 6. Model Results on Total Sales and Payroll by Employer Firm Status

\begin{tabular}{|l|l|l|l|l|l|l|}
\hline & \multicolumn{2}{|l|}{ Employer Firms } & \multicolumn{2}{l|}{ Non- Employer Firms } \\
\hline & Sales & Std. Err. & Payroll & Std. Err. & Sales & Std. Err. \\
\hline Transnational & 0.3693 & 0.01 & 0.3017 & 0.01 & 0.4037 & 0.01 \\
\hline Immigrant owned & -0.1270 & 0.01 & -0.2273 & 0.01 & -0.0065 & 0.01 \\
\hline Transnational * immigrant & 0.0119 & 0.02 & 0.0105 & 0.02 & 0.0166 & 0.02 \\
\hline Intercept & 7.3321 & 0.01 & 5.8389 & 0.01 & 4.3029 & 0.02 \\
\hline Adjusted R-square & 0.3524 & & 0.3227 & & 0.1394 & \\
\hline $\mathrm{N}$ & 641118 & & 635277 & & 312037 & \\
\hline
\end{tabular}

Note: OLS is conducted for all the models, separately between employer firms and non-employer firms.

The control variables (not shown) are the same as Table 4.

Table 7. Model Results on Sales and Payroll per Employee for Employer Firms

\begin{tabular}{|l|l|l|l|l|}
\hline & Sales & Std. Err. & Payroll & Std. Err. \\
\hline Transnational & 0.205 & 0.00 & 0.147 & 0.00 \\
\hline Immigrant owned & 0.052 & 0.01 & -0.042 & 0.00 \\
\hline Transnational * immigrant & 0.036 & 0.01 & 0.028 & 0.01 \\
\hline Intercept & 4.741 & 0.01 & 3.222 & 0.01 \\
\hline Adjusted R-square & 0.2397 & & 0.2012 & \\
\hline $\mathrm{N}$ & 579755 & & 578989 & \\
\hline
\end{tabular}

Note: OLS is conducted for all the employer firms. The control variables (not shown) are the same as

Table 4. 